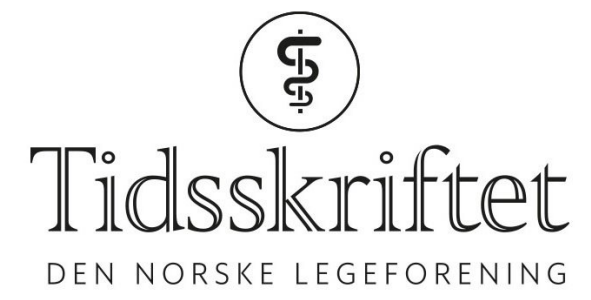

\title{
Les mer om
}

LES MER OM

\section{Leger er fortsatt mot aktiv dødshjelp}

De fleste norske leger er mot legalisering av aktiv dødshjelp, men andelen som mener at legeassistert selvmord bør tillates for personer som har «en dødelig sykdom med kort forventet levetid», er økende. Dette viser to spørreundersøkelser fra 2014 og 2016. Få leger var villige til selv å utføre legeassistert selvmord dersom dette ble tillatt.

Legenes motstand mot legalisering av aktiv dødshjelp er trolig en viktig grunn til at norske politikere ikke har tatt opp spørsmålet. Aktiv dødshjelp blir neppe innført uten støtte fra leger og andre sentrale helseprofesjoner og deres foreninger.

Originalartikkel: Legers holdninger til aktiv dødshjelp

\section{Ingen dokumentert effekt av manipulasjonsbehandling}

Manipulasjonsbehandling av spedbarn med nakkeasymmetri - torticollis - er omdiskutert. Effekten av slik behandling, som tilbys av kiropraktorer, fysioterapeuter, manuellterapeuter og osteopater, er ikke dokumentert i forskning. De få studiene som er gjort, er imidlertid usikre pga. få pasienter og usikkerhet om hva som er sanne effektestimater. Dette fremkommer av en gjennomgang av tilgjengelig forskningslitteratur. Risikoen for skade synes å være liten.

Originalartikkel: Manipulasjonsteknikker ved nakkeasymmetri hos spedbarn

\section{Crohns sykdom med fistler}

Fisteldannelse ved Crohns sykdom rammer mellom 15 og $50 \%$ av pasientene under sykdommens forløp og kan gi betydelige plager i form av smerter, sekresjon og inkontinens. Tilstanden kan være vanskelig å behandle. Behandlingen består i en kombinasjon av kirurgi og medikamenter, vanligvis biologiske legemidler som infliksimab eller adalimumab, begge tumornekrosefaktorhemmere. Antibiotika kan være gunstig i en begrenset periode, men bare i kombinasjon med immunmodulerende behandling.

Klinisk oversikt: Medikamentell behandling ved fistulerende Crohns sykdom

Publisert: 14. januar 2019. Tidsskr Nor Legeforen. DOI: 10.4045/tidsskr.19.01.03

(C) Tidsskrift for Den norske legeforening 2020. Lastet ned fra tidsskriftet.no 